\title{
Physiological potential of corn seeds treated with different dosages of molybdenum and potassium
}

\section{Potencial fisiológico de sementes de milho tratadas com diferentes doses de molibdênio e potássio}

\author{
Gisely Paula Gomes ${ }^{1 *}$; Robison Alesandro de Queiroz; \\ Lúcia Sadayo Assari Takahashi ${ }^{3}$
}

\section{Highlights}

The physiological quality of corn seeds is influenced by increasing molybdenum doses.

The number of seedlings germinating in sand increases with increasing doses.

Smaller doses of molybdenum result in a higher percentage of normal seedlings.

\begin{abstract}
Corn is important in agriculture for its dual is uses as food and animal feed. The use of quality seeds is fundamental for outcomes in the field. The treatment of seeds with molybdenum may increase the productive capacity and uniformity of the corn. For this to work, the amount applied to the seeds must be adequate to promote development and increase the final crop production. Thus, the objective of this work was to verify the effects of molybdenum and potassium application on the germination and vigor of corn seeds. The physiological quality of the seeds was evaluated by germination, first count, seedling length (shoot and root), seedling dry matter mass, emergence, and the cold test. Six treatments (T1-T6) were performed, with T1 free of molybdenum and potassium and the others with varying dosages. The seeds were treated with a commercial product that containing molybdenum and potassium. The design was completely randomized, with four replications and six treatments. Smaller doses of molybdenum resulted in a higher percentage of normal seedlings. Based on the length and dry mass of the seedlings, it was verified that maize seeds were negatively impacted by increasing doses of molybdenum and potassium. In the emergence tests in sand, treatments T5 and T6 presented a greater number of seedlings. The physiological quality of corn seeds was not significantly influenced by the application of molybdenum and potassium in the first count and germination results in the cold and germination tests.
\end{abstract}

Key words: Zea mays. Micronutrients. Emergence. Germination. Vigor.

1 Pós-Doutoranda de Fitotecnia, Programa de Pós-Graduação em Agronomia, Departamento de Agronomia, Universidade Estadual de Londrina, UEL, Londrina, PR, Brasil. E-mail: gipgomes@yahoo.com.br

2 Eng ${ }^{\circ}$ Agr $^{\circ}$, Universidade Estadual de Londrina, UEL, Londrina, PR, Brasil. E-mail: robsonagro2014@gmail.com

3 Prof ${ }^{a}$ Dra Sênior, Departamento de Agronomia, Programa de Pós-Graduação em Agronomia, UEL, Londrina, PR, Brasil, Bolsista Produtividade da Fundação Araucária. E-mail: sadayo@uel.br

* Author for correspondence

Received: Aug. 02, 2020 - Approved: Oct. 16, 2020 


\section{Resumo}

O milho possui importância no cenário agrícola e é utilizado na alimentação humana e animal. O uso de sementes de qualidade é fundamental para o desempenho desta no campo. $\mathrm{O}$ tratamento de sementes com molibdênio pode contribuir para o aumento da capacidade produtiva e maior uniformidade do milho, desta maneira, a quantidade aplicada desse elemento nas sementes deve ser adequada para provir o desenvolvimento e a produção da cultura. Assim, o objetivo deste trabalho foi verificar os efeitos da aplicação de molibdênio e potássio sobre a germinação e o vigor de sementes de milho. A qualidade fisiológica das sementes foi avaliada por meio dos testes de germinação, primeira contagem, comprimento da plântula (parte aérea e raiz), massa da matéria seca de plântula, emergência e teste de frio. Foram realizados seis tratamentos (T1- T6) sendo, T1 ausente de molibdênio e potássio e os demais com diferentes dosagens do produto. As sementes foram tratadas com produto comercial composto por molibdênio e potássio. 0 delineamento foi inteiramente casualizado, com quatro repetições e seis tratamentos. Doses menores de molibdênio favoreceram uma maior porcentagem de plântulas normais. Verificou-se pelos testes de comprimento e massa seca das plântulas, que as sementes de milho foram influenciadas negativamente por doses crescentes de molibdênio e potássio. No teste de emergência em areia os tratamentos T5 e T6 apresentam um maior número de plântulas. A qualidade fisiológica das sementes de milho não foi influenciada significativamente pela aplicação de doses de Molibdênio e potássio na primeira contagem e germinação no teste de frio e no teste de germinação.

Palavra-chave: Zea mays. Micronutrientes. Emergência. Germinação. Vigor.

The corn crop (Zea mays) is one of the oldest cultivated species in the world and is of great economic importance globally. It is the second largest crop by agricultural production in Brazil, surpassed only by soybeans, with approximately 18.5 million hectares planted in the $2019 / 2020$ harvest, and a total production of 102.5 million tonnes (Companhia Nacional de Abastecimento [CONAB], 2020).

Corn is one of the most cultivated cereals on all continents and is one of the most important crops for Brazil due to its profitability, extensive cultivation area, and use as human and animal food and as a raw material in industry (Benedeti et al., 2016). To improve productivity, new technologies related to seed production and physiological quality have been used. Quality seeds and good management practices are essential for successful maize culture, ensuring the proper establishment of plants in the field.

The use of high-vigor seeds ensures an adequate population of plants, even with climatic variation, and allows increased production when the density of plants is lower. Seed treatment can contribute to increased productivity and greater uniformity in the field. In this way, in addition to traditional fertilization via the soil, many producers are using seed treatment to supplement the supply of nutrients to plants (Evangelista et al., 2010).

Micronutrients are required in small quantities by corn plants, and can move to the plant by translocation when applied to the seed. Molybdenum (Mo) is a micronutrient required in small quantities by plants; however, 
it plays an indispensable role in the assimilation of absorbed nitrate as a component of nitrate reductase. Molybdenum deficiency can influence productivity, as it precede the formation of ascorbic acid, chlorophyll content, and respiratory activity (Taiz \& Zeiger, 2013; Silva et al., 2018).

The quality of seeds associated with appropriate cultivation practices is of paramount importance for the success of any crop. To favor uniformity, seed treatment is widely used as an easy and low-cost technique that promotes high yield. In addition, to improve the productive potential of plants, micronutrient additives have been incorporated into the seeds. Fertilization practices via seeds, with the use of micronutrients, has become more and more common, but high dosages can affect the seeds and impact the physiological quality (Pereira et al., 2012; Silva et al., 2018).

To supply molybdenum via nutrients in the seed, a sufficient dose must be transported to the plant. High doses of Mo can be toxic. In addition, high salt concentrations around seeds can impair the emergence of seedlings (Leite, Araujo, Miranda, Vieira, \& Pires, 2009). In Brazil, some studies have examined micronutrients, but there is still uncertainty regarding the sources, doses, methods, and appropriate application times (Pereira et al., 2012; Silva et al., 2018). Losses have occurred due to the incorrect use of micronutrients in corn, thus resulting in toxicity and deficiency in the absorption of other elements (Malavolta, 2006). Thus, more studies on micronutrients in seed treatment are needed. In view of the above, the objective of this research was to evaluate the physiological quality of corn seeds treated with different doses of molybdenum and potassium.
The experiment was conducted at the Seed Analysis Laboratory of the Department of Agronomy of the State University of Londrina, Londrina-PR. Zea mays L. corn seeds of the DKB 330PRO3 variety were used. The product used for seed treatment was Potamol in a liquid formulation composed of $14 \%$ molybdenum and $12 \%$ potassium $(\mathrm{K})$ with a density of $1.3 \mathrm{~kg}$ $\mathrm{L}^{-1}$. Six treatments were performed with four repetitions.

The treatments consisted of a controlT1 (with no nutrients), T2 $(0.3 \mathrm{ml}$ of the commercial product $+1.7 \mathrm{ml}$ of water $)$, T3 $(0.5 \mathrm{ml}$ of the product $+1.5 \mathrm{ml}$ of water), T4 $(0.65 \mathrm{ml}$ of the product $+1.35 \mathrm{ml}$ of water, as recommended by the manufacturer), T5 $(0.85 \mathrm{ml}$ of the product $+1.15 \mathrm{ml}$ of water), and $\mathrm{T} 6$ ( $1 \mathrm{ml}$ of the product $+1 \mathrm{ml}$ of water). In all treatments, $200 \mathrm{~g}$ of seeds were used. The nutrients were placed in a plastic bag $(20 \mathrm{~cm} \times 30 \mathrm{~cm})$ together with the water and incorporating, and then the seeds were placed inside the plastic bag and shaken for $3 \mathrm{~min}$. After that, the germination and vigor tests were conducted.

The germination test was performed with four replications of 50 seeds per treatment, were distributed among three sheets of paper towels previously moistened with 2.5 times its mass in distilled water, and placed in a germination chamber maintained at a constant temperature of $25^{\circ} \mathrm{C}$. The percentage of normal seedlings was determined on the fourth and seventh days after the test began (Ministério da Agricultura, Pecuária e Abastecimento [MAPA] 2009). To maintain the substrate humidity, the paper towel rolls were packed in plastic bags. The results are expressed as a percentage. The first germination count is the determination of the percentage of normal seedlings four days after the germination test began (MAPA, 2009). 
The evaluation of shoot and root length (SL and RL) was performed with four repetitions of 10 seeds for each treatment. Rolls of paper towels were used as the substrate previously moistened with water at the proportion of 2.5 times the weight of the paper. The seeds were distributed in two longitudinal straight lines in the upper third of the paper. After the rolls were made, they were placed in plastic bags positioned vertically. They were kept in a germinator at a constant temperature of 25 ${ }^{\circ} \mathrm{C}$. On the fourth day after sowing, the lengths of the aerial parts and roots of ten normal seedlings were determined in $\mathrm{mm}$ using a ruler.

The dry matter mass of the seedlings was assessed after the normal seedling evaluation. After the first count of the germination test, they were separated into two parts (aerial and root), packed in paper bags, and oven-dried at $60 \pm 5{ }^{\circ} \mathrm{C}$ until they reached a constant mass. They were then weighed on an analytical balance with three-digit precision. The results are expressed in grams per seedling for the aerial and root parts.

For the emergence of seedlings in sand, four repetitions of 50 seeds were sown in plastic boxes with sand as the substrate, moistened according to the Rules for Seed Analysis (MAPA, 2009). Seedlings were counted on the twenty-fifth day after sowing. The results are expressed as a percentage.
The cold test was conducted using the paper towel roll methodology without soil, with four repetitions of 50 seeds. The seeds were placed between three sheets of paper towels moistened with water at a proportion of 2.5 times the substrate mass, as in the germination test. After sowing, the rolls were placed inside sealed polyethylene plastic bags for better humidity control and kept in a chamber at 10 ${ }^{\circ} \mathrm{C}$ for seven days, and later were transferred to a germinator at $25^{\circ} \mathrm{C}$ for another seven days after the normal seedling count. The results are expressed as a percentage.

The design was completely randomized and Tukey's test was used for comparison between means. All analyses were performed using R (http://www.r-project.org).

The results of the analyses characterizing the physiological quality of the seeds in the cold test are shown in Table 1. There was no significant difference for the first count of normal seedlings and radicles at four days in the cold test. However, the highest percentages of abnormal plants in the first germination count were found in the treatments with the highest doses (T5 and T6), $9.7 \%$ and $10.2 \%$, respectively. The T4 treatment (standard) with 93\% normal seedlings stood out with the lowest percentage of abnormal seedlings, $5 \%$. 
Table 1

Average data obtained from normal seedlings (\%) and abnormal seedlings (\%) in the cold test at seven days

\begin{tabular}{lcccc} 
& \multicolumn{4}{c}{ Cold test } \\
\cline { 2 - 5 } Treatment & \multicolumn{2}{c}{ First germination count test } & \multicolumn{2}{c}{ Germination test } \\
\cline { 2 - 5 } Normal seedlings & Abnormal seedlings & Normal seedlings & Abnormal seedlings \\
T1 & $92.0 \mathrm{a}$ & $8.0 \mathrm{ab}$ & $99.5 \mathrm{a}$ & $0.5 \mathrm{~b}$ \\
T2 & $91.0 \mathrm{a}$ & $8.5 \mathrm{ab}$ & $97.5 \mathrm{a}$ & $2.5 \mathrm{~b}$ \\
T3 & $92.0 \mathrm{a}$ & $7.5 \mathrm{ab}$ & $92.0 \mathrm{a}$ & $8.0 \mathrm{a}$ \\
T4 & $93.0 \mathrm{a}$ & $5.0 \mathrm{~b}$ & $94.0 \mathrm{a}$ & $6.0 \mathrm{a}$ \\
T5 & $90.3 \mathrm{a}$ & $9.7 \mathrm{a}$ & $92.0 \mathrm{a}$ & $8.0 \mathrm{a}$ \\
T6 & $89.8 \mathrm{a}$ & $10.2 \mathrm{a}$ & $91.5 \mathrm{a}$ & $8.5 \mathrm{a}$ \\
CV\% & 2.97 & 3.30 & 4.90 & 5.01
\end{tabular}

Means followed by different letters within each methodology differ by Tukey's test, $p<0.05$.

The vigor of the seeds can be verified by the cold test after exposure to stress factors, allowing the selection of seeds of better physiological quality. There were no significant differences in the germination percentage of normal seedlings in the cold test. Similar results were reported by Chagas, Reis, Acosta, Rodriges and Vieira (2015); in evaluating soybean seeds they found no significant change in the first germination count, germination test, or cold test with increasing molybdenum doses. Regarding the percentage of abnormal seedlings, the T1 treatment without nutrients yielded $0.5 \%$ abnormal seedlings and $\mathrm{T} 2$ yielded $2.5 \%$. The germination percentage of abnormal seedlings correlated with dose (Table 1).

Hard seeds were found in treatments T2, T3, T4, and T5. Seedlings had good root development in all treatments, even after stress. According to Barros, Dias, Cícero and Krzyzanowski (1999), when the seeds are less vigorous, suffering low temperature and high humidity stress, they reduce their germination speed, thus favoring the development of microorganisms that can promote seed deterioration. This was not the case in this work; the seeds were vigorous with germination above $90 \%$.

According to Marcos (2015), 85\% germination in the cold test does not mean that this percentage of seedlings will survive in the field; however, after the cold test, there is a greater probability of survival in the field under stress conditions. The vigor tests are of great relevance due to the relationship with the emergence of seedlings in the field. In this way, it is possible to predict the performance of the seeds at sowing.

Table 2 shows the average length of the aerial part and the root. For the aerial part, there were significant differences between treatments; the seedlings that presented the largest lengths of the aerial part were from treatments $\mathrm{T} 1$ and $\mathrm{T} 2$. The total lengths of seedlings in T1, T2, and T3 were 22.05, 22.15, and $19.1 \mathrm{~cm}$ respectively. The lengths of the roots and aerial parts were significantly different between treatments. Seedlings had shorter RL and SL in the T6 treatment, with the highest product dosage. 
The weight of the dry mass of the seedling root was highest in T1 at $0.2225 \mathrm{~g}$, and for the aerial part it was highest in T1, T2, and T3. The lowest weights of root dry mass were from treatments T3 and T6; however, the weight of the dry mass of the aerial part was lower in T6. There was a reduction in seedling length and dry mass with increasing doses (Table 2).

\section{Table 2}

Shoot length (SL), root length (RL), root dry mass (RDM), shoot dry mass (SDM), first emergence count (FEC), emergence (E), first germination count test (FGC), and germination test (G) of corn seeds with different molybdenum treatments

\begin{tabular}{|c|c|c|c|c|c|c|c|c|}
\hline \multirow[b]{2}{*}{ Treatment } & \multicolumn{2}{|c|}{ Length (cm) } & \multicolumn{2}{|c|}{ Shoot dry mass (g) } & \multicolumn{2}{|c|}{ Emergence (\%) } & \multicolumn{2}{|c|}{ Germination (\%) } \\
\hline & SL & $\mathrm{RL}$ & RDM & SDM & FEC & E & FGC & G \\
\hline T1 & $14.05 \mathrm{a}$ & $8.00 \mathrm{a}$ & $0.2225 a$ & $0.2725 a$ & $3.50 \mathrm{c}$ & $19.5 \mathrm{c}$ & $52.0 \mathrm{a}$ & $99.5 a$ \\
\hline T2 & $13.45 a$ & $8.70 \mathrm{a}$ & $0.1900 \mathrm{~b}$ & $0.2825 a$ & $3.00 \mathrm{c}$ & $34.5 \mathrm{~b}$ & $54.0 \mathrm{a}$ & $97.5 \mathrm{a}$ \\
\hline T3 & $11.30 \mathrm{~b}$ & $7.80 \mathrm{a}$ & $0.1375 \mathrm{c}$ & $0.2550 \mathrm{a}$ & $4.30 \mathrm{c}$ & $18.5 \mathrm{c}$ & $50.0 \mathrm{a}$ & $92.0 \mathrm{a}$ \\
\hline T4 & $11.40 \mathrm{~b}$ & $7.30 \mathrm{a}$ & $0.1627 \mathrm{~b}$ & $0.2325 b$ & $6.50 \mathrm{~b}$ & $36.5 b$ & $51.5 a$ & $94.0 \mathrm{a}$ \\
\hline T5 & $9.45 \mathrm{c}$ & $7.50 \mathrm{a}$ & $0.1544 \mathrm{~b}$ & $0.2275 b$ & $13.0 \mathrm{a}$ & $50.0 a$ & $50.7 \mathrm{a}$ & $92.0 \mathrm{a}$ \\
\hline T6 & $7.80 \mathrm{c}$ & $5.10 \mathrm{~b}$ & $0.1200 \mathrm{c}$ & $0.18500 \mathrm{c}$ & $14.5 \mathrm{a}$ & $71.5 \mathrm{a}$ & $51.5 a$ & $91.5 \mathrm{a}$ \\
\hline CV\% & 12.02 & 13.50 & 13.02 & 12.44 & 24.00 & 20.40 & 4.34 & 4.57 \\
\hline
\end{tabular}

Means followed by different letters within each methodology differ by Tukey's test, $p<0.05$.

The data for the first emergence count of seedlings in sand indicate the superiority of treatments T5 and T6. These results show lower performance for the T1, T2, and T3 treatments. The seedling emergence tests in sand were significant at $p<0.05$ (Table 2). The percentage of seedlings emerging in sand at 14 days after sowing was highest in treatments T5 and T6, with the higher doses of molybdenum. Treatments T2 and T4 yielded the second-best performance for emergence.

With the increase in doses of commercial fertilizer containing molybdenum and potassium, there was no reduction in the percentage of germination in the first count and germination tests of corn seeds. The application of the product likely did not cause a phytotoxic effect while the seeds were exposed to the treatments or compromise the embryo. It was demonstrated that the commercial fertilizer seed treatment did not cause a reduction in vigor or in the germination percentage of corn seedlings.

Similar data were obtained by Nunes et al. (2017) in cowpea seeds, where the effect of molybdenum content was not significant in the germination test. However, Pereira et al. (2012) found that the first germination count of corn seeds was negatively influenced by increasing doses of molybdenum, probably caused by damage to the seed embryo by high concentrations of salt in the seed. Oliveira, Schuch, Bruno and Peske (2015), evaluating the physiological quality of cowpea seeds, observed that treatment with the micronutrient product COMOL 118 (1\% cobalt and 8\% molybdenum) yielded seeds similar to those not treated with the product. 
Otherstudiesconducted withproducers found that when micronutrients are applied via seed treatment in high salt concentrations, such as molybdate, germination is decreased and delayed, reducing the crop stand and consequently the productivity (Gonçalves \& Pessoa, 2002; Luchese, Gonçalves, Luchese, \& Braccini, 2004).

These results are probably related to a greater sensitivity of the seeds to the chemical components of the product used, negatively affecting the physiological performance of the seeds, as mentioned. In addition, absorption of the fertilizer has several aspects, such as the water content of the solution, the concentration of the solution, and the exposure time of the seeds; depending on these aspects, the physiological performance of the seeds may or may not be compromised.

With increasing doses of molybdenum and potassium, there was an increase in the number of seedlings germinating in sand and in the number of abnormal seedlings and a reduction in seedling length and dry mass. The physiological quality of corn seeds was not significantly influenced by the application of molybdenum and potassium in the first count and germination results in the cold and germination tests.

\section{Acknowledgments}

Thank the Araucária Foundation for the productivity fellowship grant awarded to Lúcia Sadayo Assari Takahashi.

\section{References}

Barros, A. S. R., Dias, M. C. L. L., Cícero, S. M., \& Krzyzanowski, F. C. (1999). Teste de frio. In F. C. Krzyzanowski, R. D. Vieira, \& J. B. França Neto (Eds.), Vigor de sementes: conceitos e testes (pp. 1-13). Londrina: ABRATES.

Benedeti, P. D. B., Paulino, P. V. R., Marcondes, M. I., Maciel, I. F. S., Silva, M. C., \& Faciola, A. P. (2016). Partial replacement of ground corn with glycerol in beef cattle diets: intake, digestibility, performance, and carcass characteristics. PLoS One, 11(1), e0148224. doi: 10.1371/journal.pone.014 8224

Ministério da Agricultura, Pecuária e Abastecimento. (2009). Regras para análise de sementes. Brasília: MAPA/ACS. Recuperado de http://www.agricultura. gov.br/assuntos/laboratorios/arquivospublicacoes-laboratorio/regras-paraanalise-de-sementes.pdf/view.

Chagas, H. L., Reis, B. B. dos, Acosta, G. S., Rodriges, R. R., \& Vieira, J. F. (2015). Aplicação de molidbdênio via sementes e seus efeitos na nodulação, atividade enzimática e qualidade de sementes de soja. Enciclopédia Biosfera, Centro Científico Conhecer, 11(21), 190-202.

Companhia Nacional de Abastecimento (2020). Grãos, safra 2019/2020. Recuperado de http://www.conab. gov.br/conteudos. php?a $=1253$

Evangelista, J. R. E., Oliveira, J. A., Botelho, F. J. E., Carvalho, B. O., Vilela, F. de L., \& Oliveira, G. E. (2010). Qualidade fisiológica e produtividade de sementes de feijão oriundas de sementes tratadas com enraizante e nutrição mineral das plantas. Ciência e Agrotecnologia, 34(Esp.), 1664-1668. doi: 10.15 90/S141370542010000700013 
Gonçalves, A. C., Jr., \& Pessoa, A. C. S. (2002). Fitodisponibilidade de cádmio, chumbo e cromo, em soja cultivada em Argissolo Vermelho eutroférrico a partir de adubos comerciais. Revista Scientia Agraria, 3(1), 19-23. doi: 10.5380/rsa.v3i1.1026

Leite, U. T., Araujo, G. A. A., Miranda, G. V., Vieira, R. F., \& Pires, A. A. (2009). Influência do conteúdo de molibdênio na qualidade fisiológica da semente de feijão: cultivares Novo Jalo e Meia Noite. Revista Ceres, 56(2), 225-231.

Luchese, A. V., Gonçalves, A. C., Jr., Luchese, E. B., \& Braccini, M. C. L. (2004). Emergência e absorção de cobre por plantas de milho (Zea mays) em resposta ao tratamento de sementes com cobre. Revista Ciência Rural, 34(1), 1949- 1952. doi: 10.1590/ S0103-84782004000600044

Malavolta, E. (2006). Manual de nutrição mineral de plantas. São Paulo: CERES, 2006.

Marcos, J., Fo. (2015). Fisiologia de sementes de plantas cultivadas. Piracicaba: FEALQ.

Nunes, R. T. C., Souza, U. O., Araujo, A. C., Neto, Morais, O. M., Fogaça, J. J. N. L., Santos, J. L.,... São José, A. R. (2017). Produção e qualidade de sementes de feijão-caupi em função de doses de molibdénio e da população de plantas. Revista de Ciências Agrárias, 40(3), 533-542. doi: 10.19084/ RCA17028
Oliveira, L. M. de, Schuch, L. O. B., Bruno, R. de L. A., \& Peske, S. T. (2015). Qualidade de sementes de feijão-caupi tratadas com produtos químicos e armazenadas em condições controladas e não controladas de temperatura e umidade. Semina: Ciências Agrárias, 36(3), 1263-1276. doi: 10.5433/1679-0359.2015 v36n3p1263

Pereira, F. R. S., Brachtvogel, E. L., Cruz, S. C. S., Bicudo, S. J., Machado, C. G., \& Pereira, J. C. (2012). Qualidade fisiológica de sementes de milho tratadas com molibdênio. Revista BrasileiradeSementes, 34(3), 450-456. doi: 10.1590/S0101-31222012000300012

Silva, C. G. M., Moreira, S. G., Lupp, R. M., Castro, G. F. de, Rehagro, B. H. A., \& Silva, A. A. P. da. (2018). Doses de molibdênio na produtividade do milho. Revista Agrogeoambiental, 10(1), 47-55. doi: 10.18406/2316-1817v10n120181067

Taiz, L., \& Zeiger, E. (2013). Fisiologia vegetal (5a ed.). Porto Alegre: Artemed. 